\title{
Pelatihan Peningkatan Strategi Pembelajaran Berbasis Kurikulum 2013
}

\author{
Nila Fitria ${ }^{1 *}$, Fidesrinur ${ }^{1}$ \\ ${ }^{1}$ Program Studi PG PAUD, Fakultas Psikologi dan Pendidikan, Universitas Al Azhar Indonesia, \\ Komplek Masjid Agung Al Azhar, Jakarta Selatan, 12110 \\ Email Penulis Korespondensi: nilafitria84@gmail.com
}

\begin{abstract}
Kindergarten Toledo as a partner in community service activities is an Educational Institution located in Pasar Rebo, East Jakarta. This Educational Institution provides Education services for early childhood in the age range of 3-6 years. Teaching and learning activities have been carried out by the teacher but the learning is not based on the 2013 curriculum, so it can not be known the achievement or non-achievement of a learning activity based on basic competencies. The solution that will be given to teachers through community service activities funded from the LP2M UAI in the competitive public service grant program. The form of solutions to be provided are training and workshops. The training provided to teachers in the scientific approach material. The scientific approach is one of the learning strategies that must be carried out in the 2013 PAUD curriculum. Then the learning tool workshop, where the teachers compile and design a curriculum plan based on the 2013 weekly and daily activities with a scientific approach. The final stage of this activity is mentoring in practicing the 2013 curriculum-based PAUD learning strategy. The results of this activity aim to increase learning strategies in teachers at the Toledo Islamic Kindergarten at $69 \%$ who have the "Good" category. The conclusion is that the scientific learning training activities and workshops on learning tools can improve the ability of learning strategies possessed by teachers.
\end{abstract}

\section{Keywords: Learning strategies, Teachers, Curriculum 2013}

\begin{abstract}
Abstrak
TK Toledo sebagai mitra dalam kegiatan pengabdian masyarakat merupakan Lembaga Pendidikan yang terletak di daerah Pasar Rebo, Jakarta Timur. Lembaga Pendidikan ini menyelenggarakan layanan Pendidikan bagi anak usia dini dalam rentang usia 3-6 tahun. Kegiatan belajar mengajar sudah dilakukan oleh guru tetapi pembelajaran yang belum berbasis kurikulum 2013, sehingga tidak dapat diketahui ketercapaian atau ketidaktercapaian dari sebuah kegaiatan pembelajaran berdasarkan kompetensi dasar. Solusi yang akan diberikan kepada guru melalui kegiatan pengabdian kepada masyarakat yang didanai dari LP2M UAI pada program competitive public service grant. Adapun bentuk solusi yang akan diberikan adalah pelatihan dan workshop. Pelatihan yang diberikan kepada guru dalam materi pendekatan saintifik. Pendekatan saintifik merupakan salah satu startegi pembelajaran yang harus dilakukan pada kurikulum 2013 PAUD. Kemudian workshop perangkat pembelajaran, dimana guru-guru menyusun dan merancang rencana kegiatan mingguan dan harian berbasis kurikulum 2013 dengan pendekatan saintifik. Tahap akhir dari kegiatan ini adalah pendampingan dalam mempraktekkan strategi pembelajaran PAUD berbasis kurikulum 2013. Hasil dari kegiatan ini menujukan adanya peningkatan strategi pembelajaran pada guru di TK Islam Toledo sebesar 69\% yang memiliki kategori "Baik". Kesimpulannya adalah kegiatan pelatihan pendektan saintifik dan workshop tentang perangkat pembelajaran dapat meningkatkan kemampuan strategi pembelajaran yang dimiliki guru.
\end{abstract}

Kata Kunci: Strategi Pembelajaran, Guru, Kurikulum 2013 


\section{PENDAhUluan}

Kecamatan Pasar Rebo merupakan daerah yang cukup startegis karena terlentak di pintu masuk Jakarta dari selatan yaitu Propinsi Jawa Barat (Bogor) dan dilintasi oleh jalan tol lingkar luar selatan. Salah satu Taman KanakKanak yang berada di kecamatan Pasar Rebo adalah TK Islam Toledo yang berdiri pada tahun 1983 yang beralamatkan di Jalan Lapan No. 25, Pekayon Pasar Rebo - Jakarta Timur. TK Islam Toledo berada di lingkungan Pesantren Husnayain dimana KH. Ahmad Cholil Ridwan, Lc selaku pendiri dan pimpinan Pesanter Husnayain. TK Islam Toledo saat ini dikepalai oleh Tsunayya Aadillah serta memiliki 5 orang guru. Empat orang guru berlatar belakang Pendidikan S1 PAUD dan satu orang guru berlatar belakang pendidikan D2 PAUD.

Walaupun sebagian besar guru dari TK Islam Toledo berlatar belakang pendidikan Sarjana Pendidikan Anak Usia Dini, namun tidak dibarengi dengan pengetahuan dan keterampilannya mengenai Pendidikan Anak Usia Dini, dapat dilihat pada saat observasi awal di TK Islam Toledo masih banyak guru yang tidak membuat rencana pembelajaran baik rencana mingguan maupun rencana harian, guru-guru di TK Islam Toledo juga tidak menata kelas sesuai kebutuhan anak usia dini, mereka masih menggunakan posisi duduk klasikal seperti yang dilakukan di sekolah dasar. Guru-guru di TK Islam Toledo juga tidak menyiapkan alat main sebagai bahan pembelajaran untuk anak, mereka masih menggunakan Lembar Kerja Siswa (LKS) sehingga layanan pendidikan anak usia dini di TK Islam Toledo lebih terlihat seperti layanan pendidikan sekolah dasar pada saat awal observasi yang dilakukan penulis.

Layanan Pendidikan yang disediakan oleh TK Islam Toledo membutuhkan tenaga pendidik yang mampu membuat perencanaan pembelajaran berbasis kurikulum 2013 dengan prinsip belajar sambil bermain.

Melihat latar belakang Pendidikan guru yang sudah memiliki ilmu PAUD sudah sepatutnya guru dapat membuat perencanaan pembelajaran. Kenyataannya di lapangan menurut Kepala TK Islam Toledo belum semua guru memahami dan belum dapat mempraktekkan kurikulum 2013. Permasalahan yang tampak pula dimana tuntutan orang tua, anak yang lulus dari lembaga taman kanak- kanak harus memiliki kemampuan membaca, menulis, dan berhitung. Hal ini berdampak pula pada guru untuk dapat memberikan pembelajaran yang berorientasi pada Calistung.

Adapun bentuk solusi yang ditawarkan adalah workshop mengenai perangkat pembelajaran berbasis kurikulum 2013, pelatihan pendekatan saintifik, dan pendampingan. Materi kurikulum 2013 diberikan kepada guru untuk menyusun perangkat pembelajaran berupa Rencana Pelaksanaan Pembelajaran Mingguan (RPPM) dan Rencana Pelaksanaan Pembelajaran Harian (RPPH). Materi penyusunan perangkat pembelajaran diberikan kepada guru dengan harapan kegiatan ini dapat meningkatkan kemampuan guru dalam menyusun RPPM dan RPPH untuk dapat dilaksanakan dalam kegiatan belajar mengajar (KBM). Materi pendekatan saintifik diberikan kepada guru TK dengan tujuan untuk meningkatkan kemampuan guru TK mencakup 5M (Mengamati, Menanya, Mengumpulkan Informasi, Menalar, dan Menginformasikan). Target yang diharapkan guru dapat mempraktekkan pendekatan saintifik dalam kegiatan belajar mengajar berbasis kurikulum 2013.

\section{Kurikulum PAUD}

Undang-Undang Nomor 20 Tahun 2003 tentang Sistem Pendidikan Nasional menyebutkan bahwa kurikulum adalah seperangkat rencana dan pengaturan mengenai tujuan, isi, dan bahan pelajaran serta cara yang digunakan sebagai pedoman penyelenggaraan kegiaatan pembelajaran untuk mencapai tujuan Pendidikan tertentu. Kurikulum Pendidikan Anak Usia Dini merupakan seperangkat rencana yang digunakan untuk anak usia 0 - 6 tahun yang dilakukan melalui rangsangan Pendidikan untuk membantu pertumbuhan dan perkembangan anak untuk memasuki usia lanjut. Adapun karakteristik kurikulum 2013 pendidikan anak usia dini, sebagai berikut:

1. Mengoptimalkan perkembangan anak yang meliputi: aspek nilai agama dan moral, fisik motorik, kognitif, bahasa, sosial emosional, dan seni yang tercermin dalam keseimbangan kompetensi sikap, pengetahuan, dan keterampilan.

2. Menggunakan pembelajaran tematik dengan pendekatan saintifik dalam pemberian rangsangan Pendidikan. 
3. Menggunakan penilaian autentik dalam memantau perkembangan anak.

4. Memberdayakan peran orang tua dalam proses pembelajaran.

Sedangkan dalam Peraturan Menteri No. 146 Tahun 2014, tujuan kurikulum 2013 Pendidikan Anak Usia Dini untuk mendorong berkembngnya potensi anak agar memiliki kesiapan untuk menempuh Pendidikan selanjutnya.

\section{Strategi Pembelajaran}

Dalam Kamus Besar Bahasa Indonesia, strategi adalah rencana yang cermat mengenai kegiatan untuk mencapai sasaran khusus (yang diinginkan). Joni (dalam Hamdani, 2011) berpendapat bahwa yang dimaksud strategi adalah suatu prosedur yang digunakan untuk memberikan suasana yang konduktif kepada siswa dalam rangka mencapai tujuan pembelajaran. Menurut Gerlach dan Ely, apabila dihubungkan dengan proses belajar mengajar strategi adalah pengajaran tertentu yang meliputi sifat, lingkup dan urutan kegiatan yang dapat memberikan pengalaman belajar kepada siswa. Dick dan Carey menambahkan, strategi belajar tidak hanya terbatas pada prosedur kegiatan, tetapi juga termasuk di dalamnya materi atau paket pengajarannya.

Kemp (dalam Sumar, 2016) menyebutkan Strategi pembelajaran adalah suatu kegiatan pembelajaran yang harus dikerjakan oleh guru dan siswa untuk mencapai suatu tujuan pembelajaran yang efektif dan efisisen. Senada anda Carey (dalam Sumar, 2016) menyebutkan strategi pembelajaran yang digunakan secara bersama-sama untuk menimbulkan hasil belajar pada siswa. Strategi pembelajaran (Nata, 2009) merupakan salah satu komponen pendidikan yang bersifat terapan - aplikatif dengan berdasar pada berbagai teori dan konsep keilmuan yang relevan, seperti psikologi, sosiologi, komunikasi, dan lain sebagainya. Strategi belajar mengajar ini terdiri atas semua komponen materi pengajaran dan prosedur yang akan digunakan untuk membantu siswa mencapai tujuan pengajaran tertentu. Dengan kata lain, strategi belajar mengajar juga merupakan pemilihan jenis latihan tertentu yang cocok dengan tujuan yang akan dicapai (Gropper dalam Hamdani, 2011).

Di Indonesia pembelajaran kini menggunakan kurikulum terbaru yakni kurikulum 2013. Begitu pula dengan lembaga PAUD, Kurikulum PAUD 2013 dibuat dengan tujuan mendorong perkembangan anak didik secara optimal. Maka dapat disimpulkan bahwa strategi pembelajaran adalah cara guru dan siswa untuk mencapai tujuan pembelajaran berbasis kurikulum PAUD 2013.

Dalam hal ini strategi pembelajaran anak usia dini, harus memperhatikan model pembelajaran yang dilakukan di sekolah. Dengan mengetahui model pembelajaran yang dilakukan dalam kegiatan belajar mengajar, maka guru akan merancang stategi untuk mencapai tujuan pembelajaran. Tercapainya tujuan pembelajaran akan diadministrasikan dalam rencana pelaksanaan pembelajaran harian (RPPH) sebagai bentuk kegiatan yang telah dilaksanakan. Pentingnya memiliki kemampuan strategi pembelajaran pada guru sebagai bentuk guru telah memiliki kompetensi pedagogik yang baik.

\section{METODOLOGI PELAKSANAAN}

Metode yang digunakan metode deskriptif kuantitatif dengan desain pre-test - post-test control group design. Dilakukan dengan melakukan pengukuran (pre-test) sebelum kegiatan dan (post-test) dengan memberikan intervensi.

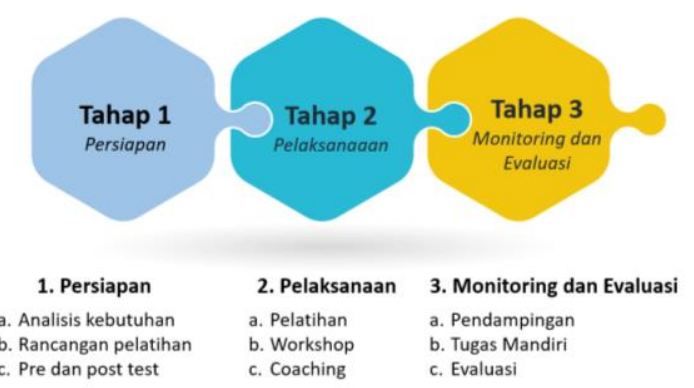

Gambar 1. Alur Metode Pelaksanaan

\section{Instrumen}

Instrument yang digunakan dalam pengabdian masyarakat dengan tujuan untuk memperoleh data tentang strategi pembelajaran melalui tindakan kelas.

Data yang diperoleh dari hasil observasi strategi pembelajaran dioleh dan kemudian dihitung presentase serta nilai rata-ratanya. Adapun presentase ketuntasan sesuai dengan kriteria ketuntasan dalam Tabel 1. 
Tabel 1. Kriteria Ketuntasan

\begin{tabular}{ll}
\hline $\begin{array}{l}\text { Presentase } \\
\text { Ketuntasan }\end{array}$ & Klasifikasi \\
\hline$>80$ & Sangat Baik \\
$>60-80$ & Baik \\
$>40-60$ & Cukup \\
$>20-40$ & Kurang \\
$<20$ & Sangat kurang \\
\hline
\end{tabular}

Data yang dianalisa dalam presentase menggunakan rumus (dalam Marliza, 2012: 450) sebagai berikut:
$\mathrm{P}=\frac{\mathrm{F}}{\mathrm{N}} \times 100 \%$

Keterangan :

$\mathrm{P}=$ Angka presentasi

$\mathrm{F}=$ Frekuensi aktifitas /skor

$\mathrm{N}=$ Jumlah guru

Berdasarkan kriteria ketuntasan di atas, maka kriteria keberhasilan dinyatakan berhasil apabila $75 \%$ dari jumlah guru yang mendapatakan nilai 3 pada masing-masing indicator penilaian.

\section{HASIL DAN PEMBAHASAN}

Tabel 2. Rekapitulasi Observasi Strategi Pembelajaran Guru TK Toledo pada Siklus I

\begin{tabular}{|c|c|c|c|c|c|c|c|c|c|c|c|c|c|c|c|c|c|c|}
\hline Siklus 1 & \multicolumn{3}{|c|}{ Penataan Kelas } & \multicolumn{3}{|c|}{ Display Tema } & \multicolumn{3}{|c|}{ Kegiatan Pembuka } & \multicolumn{3}{|c|}{ Kegiatan Inti } & \multicolumn{3}{|c|}{$\begin{array}{c}\text { Pemilihan } \\
\text { Penggunaan Media }\end{array}$} & \multicolumn{3}{|c|}{ Kegiatan Penutup } \\
\hline \multirow{3}{*}{ Pertemuan 1} & 1 & 2 & 3 & 1 & 2 & 3 & 1 & 2 & 3 & 1 & 2 & 3 & 1 & 2 & 3 & 1 & 2 & 3 \\
\hline & 4 & 0 & 0 & 4 & 0 & 0 & 4 & 0 & 0 & 4 & 0 & 0 & 4 & 0 & 0 & 4 & 4 & 5 \\
\hline & $100 \%$ & $0 \%$ & $0 \%$ & $100 \%$ & $0 \%$ & $0 \%$ & $100 \%$ & $0 \%$ & $0 \%$ & $100 \%$ & $0 \%$ & $0 \%$ & $100 \%$ & $0 \%$ & $0 \%$ & $100 \%$ & $0 \%$ & $0 \%$ \\
\hline \multirow{4}{*}{ Pertemuan 2} & \multicolumn{3}{|c|}{ Penataan Kelas } & \multicolumn{3}{|c|}{ Display Tema } & \multicolumn{3}{|c|}{ Kegiatan Pembuka } & \multicolumn{3}{|c|}{ Kegiatan Inti } & \multicolumn{3}{|c|}{$\begin{array}{c}\text { Pemilihan } \\
\text { Penggunaan Media }\end{array}$} & \multicolumn{3}{|c|}{ Kegiatan Penutup } \\
\hline & 1 & 2 & 3 & 1 & 2 & 3 & 1 & 2 & 3 & 1 & 2 & 3 & 1 & 2 & 3 & 1 & 2 & 3 \\
\hline & 4 & 0 & 0 & 3 & 1 & 0 & 2 & 2 & 0 & 3 & 1 & 0 & 4 & 0 & 1 & 4 & 0 & 0 \\
\hline & $100 \%$ & $0 \%$ & $0 \%$ & $75 \%$ & $25 \%$ & $0 \%$ & $50 \%$ & $50 \%$ & $0 \%$ & $75 \%$ & $25 \%$ & $0 \%$ & $100 \%$ & $0 \%$ & $25 \%$ & $50 \%$ & $50 \%$ & $0 \%$ \\
\hline \multirow[t]{2}{*}{$\begin{array}{c}\text { Rata-rata } \\
\text { ketercapaian }\end{array}$} & $100 \%$ & $0 \%$ & $0 \%$ & $88 \%$ & $13 \%$ & $0 \%$ & $75 \%$ & $25 \%$ & $0 \%$ & $88 \%$ & $13 \%$ & $0 \%$ & $100 \%$ & $0 \%$ & $13 \%$ & $75 \%$ & $25 \%$ & $0 \%$ \\
\hline & & $0 \%$ & & & $13 \%$ & & & $50 \%$ & & & $13 \%$ & & & $13 \%$ & & & $25 \%$ & \\
\hline
\end{tabular}

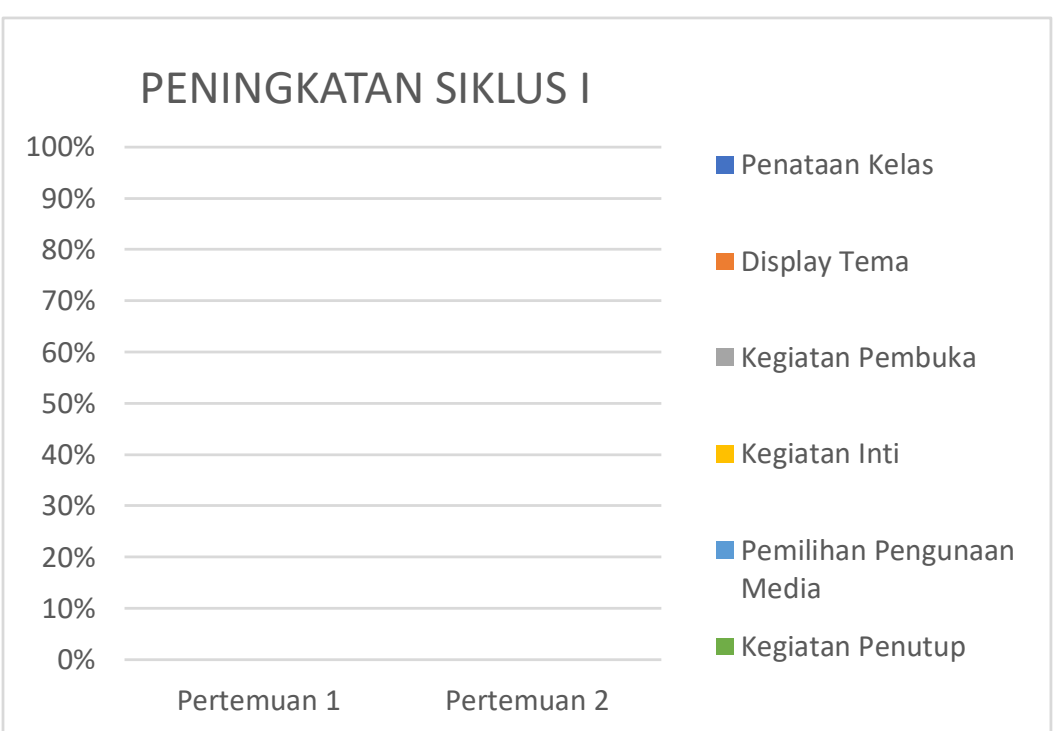

Gambar 2. Peningkatan Tiap Pertemuan Dilihat dari Seberapa Banyak Guru yang Mendapat Nilai 3 
Tabel 3. Rekapitulasi Observasi Strategi Pembelejran Guru pada Siklus II

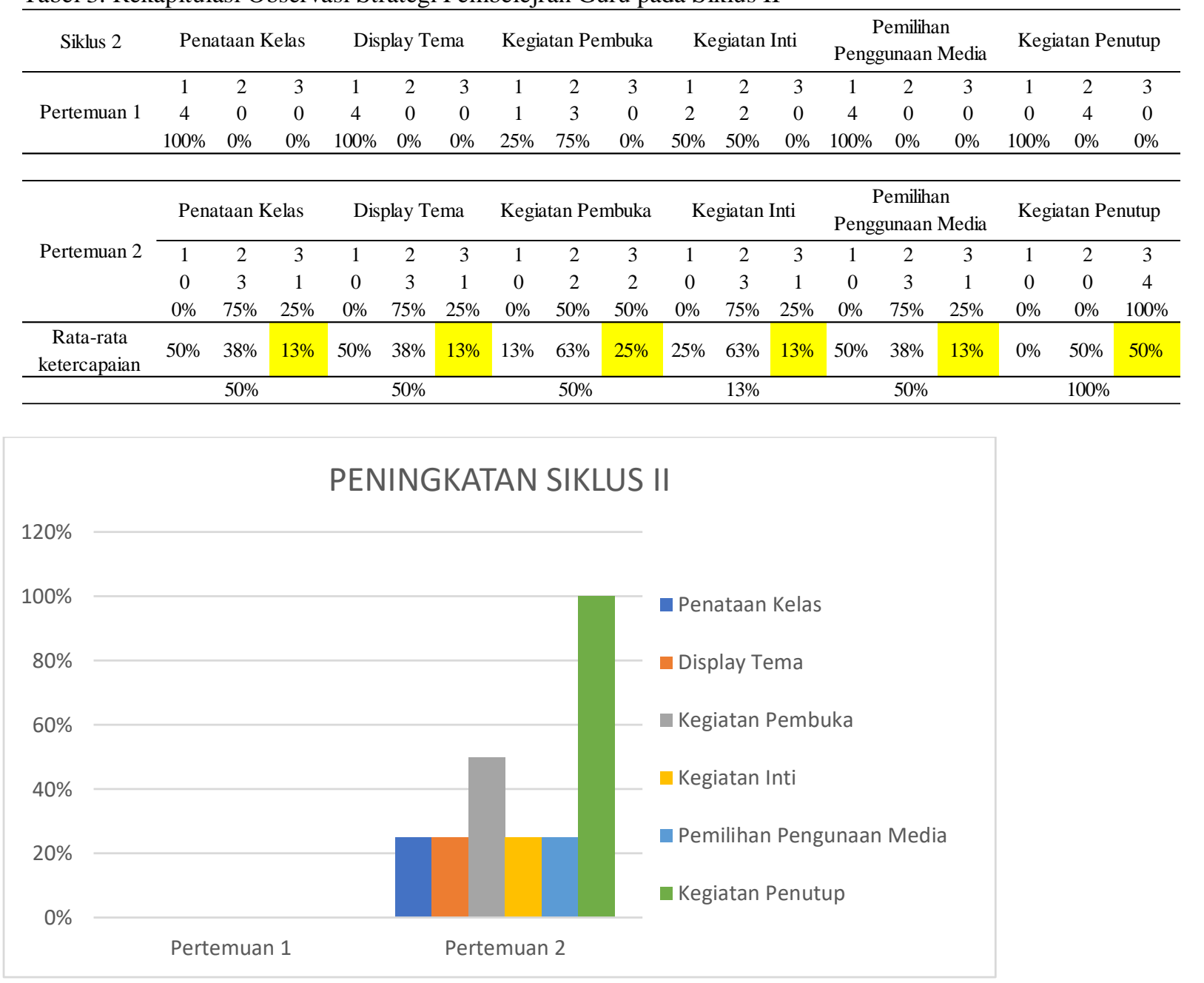

Gambar 3. Peningkatan Siklus II Dilihat Dari Seberapa Banyak Guru yang Mendapatkan Skor 3

Berdasarkan hasil yang diperoleh pada siklus 1 dan silus 2 dapat terlihat terjadi peningkatan pada presentase strategi pembelajaran di setiap pertemuan. Hal ini dapat dilihat pada Tabel 4.

Tabel 4. Perbandingan Presentase Strategi Pembelajaran di Setiap Pertemuan

\begin{tabular}{|c|c|c|c|c|}
\hline No & Indikator Penilaian & $\begin{array}{c}\text { Rata-Rata } \\
\text { Ketercapaian } \\
\text { Siklus } 1\end{array}$ & $\begin{array}{c}\text { Rata-Rata } \\
\text { Ketercapaian } \\
\text { Siklus } 2\end{array}$ & Peningkatan \\
\hline 1. & Penataan Kelas & $0 \%$ & $50 \%$ & $50 \%$ \\
\hline 2. & Display Tema & $13 \%$ & $50 \%$ & $37 \%$ \\
\hline 3. & Kegiatan Pembuka & $50 \%$ & $88 \%$ & $38 \%$ \\
\hline 4. & Kegiatan Inti & $13 \%$ & $75 \%$ & $62 \%$ \\
\hline 5. & $\begin{array}{l}\text { Pemilihan } \\
\text { penggunaan Media }\end{array}$ & $13 \%$ & $50 \%$ & $37 \%$ \\
\hline 6. & Kegiatan Penututp & $25 \%$ & $100 \%$ & $75 \%$ \\
\hline \multicolumn{4}{|c|}{ Rata-rata peningkatan } & $49,83 \%$ \\
\hline
\end{tabular}

Oleh karena itu, dengan adanya peningkatan pada siklus 2 pada strategi pembelajaran guru.
Peningkatan pada penataan kelas $50 \%$, display tema $37 \%$, kegiatan pembukaan $38 \%$, kegiatan 
inti $62 \%$, pemilihan media $37 \%$ dan kegiatan penutup $75 \%$.

Berdasarkan data yang diperoleh, dapat dikatakan bahwa tindakan yang dilakukan telah berhasil karena nilai yang diperoleh sudah mengalami peningkatan sesuai dengan indikator strategi pembelajaran. Kemp (dalam Sumar, 2016) menyebutkan Strategi pembelajaran adalah suatu kegiatan pembelajaran yang harus dikerjakan oleh guru dan siswa untuk mencapai suatu tujuan pembelajaran yang efektif dan efisisen. Melalui strategi pembelajaran yang telah dilakukan dengan model sentra, dalam pelaksanaannya guru efektif mulai dari diterapkannya penulisan kegiatan hari ini di kelas. Pada saat itu pula anak bertanya dengan adanya perubahan terkait adanya penulisan kegiatan yang akan dilakukan hari ini di papan tulis.

Dick dan Carey menambahkan, strategi belajar tidak hanya terbatas pada prosedur kegiatan, tetapi juga termasuk di dalamnya materi atau paket pengajarannya. Guru telah menyiapkan materi yang akan disiapkan dalam pembelajaran. Terlihat dari penulisan kegiatan hari ini di papan tulis, penataan ruang belajar, media yang digunakan, serta display tema secara sederhana di masing-masing kelas. Kegiatan pembukaan yang diawali dengan pembiasaan ikrar dan doa bersama - sama. Setelah berdoa bersama selesai, anak masuk ke sentra masing-masing sesuai dengan jadwal sentra yang telah dibuat. Ketika di sentra masing-masing, guru sentra sudah menyiapkan pijakan main agar anak dapat bermain di sentra. Sehingga tujuan pembelajaran dapat tercapai seperti yang disampaikan oleh Gropper bahwa strategi belajar mengajar juga merupakan pemilihan jenis latihan tertentu yang cocok dengan tujuan yang akan dicapai (Gropper dalam Hamdani, 2011).

\section{KESIMPULAN DAN SARAN}

Berdasarkan hasil data yang diperoleh dapat disimpulkan bahwa terdapat peningkatan dalam strategi pembelajaran. Peningkatan rata-rata guru yang mendapat skor 2 dan skor 3 apada setiap siklus 1 ke siklus 2 pada indikator penataan kelas $50 \%$, dalam arti kelas sudah mulai di tata dengan model pembelajaran sentra. Pada indikator display tema terdapat peningkatan sebesar 50\% dimana guru memajang gambar yang terkait dengan tema walau dalam bentuk gambar sederhana.

Pada indikator kegiatan pembuka terdapat peningkatan sebesar $88 \%$ dimana guru menuliskan kegiatan hari ini di papan tulis sesuai dengan temanya. Pada kegiatan inti terdapat peningkatan $75 \%$ dimana guru menata pijakan main di sentra. Untuk pemilihan penggunaan media terdapat peningkatan sebanyak 50\% dimana guru yang sebelumnya hanya menggunakan buku paket sebagai media, setelah diberikan tindakan sudah menggunakan media dalam proses pembelajaran. Pada indikator kegiatan penutup, terdapat peningkatan sebanyak 50\% dimana guru sudah berdoa, salam, memberikan kegiatan esok hari, dan melaksanakan relaksasi (bernyanyi, mendengarkan cerita) serta mendiskusikan kegiatan yang sudah dilaksanakan di sentra.

Berdasarkan hasil pengabdian masyarakat, maka terdapat beberapa saran di antaranya; (a) Guru dapat meningkatkan strategi pembelajaran yang sudah dimiliki sesuai dengan model pembelajaran yang diterapkan. (b) Guru dapat meningkatkan pengetahuan tentang stategi pembelajaran dengan model sentra dengan mengikuti pelatihan, seminar, workshop, (c) Kepala TK memonitor proses pembelajaran khususnya stategi pembelajarn guru ketika mengajar, (d) Kepala TK perlu merancang bersama guru dalam mengembangkan strategi pembelajaran di sekolah.

\section{DAFTAR PUSTAKA}

Hamdani. (2011). Strategi Belajar Mengajar. Bandung: Pustaka Setia.

Kemendikbud. (2014). Peraturan Menteri Nomor. 146 tahun 2014. Jakarta.

Nata. Abuddin. (2009). Perspektif Islam dalam Strategi Pembelajaran. Kencana, Jakarta.

Sumar. Tune Warni dan Razak, Intan Abdul. (2016). Strategi Pembelajaran dalam Implementasi Kurikulum Berbasis Soft Skill. Deepublish, Yogyakarta. 